\title{
COVID-19 Awareness and Its Impact in Rural and Urban Puducherry - A Community Based Cross Sectional Study
}

\author{
Rajini Senthil11, Balagurunathan Kunchithapathan², Sivapragasam Ramalingam³ ${ }^{3}$ Ponmalar Manivannan ${ }^{4}$ \\ 1,3,4 Department of Community Medicine, Sri Lakshmi Narayana Institute of Medical Sciences, \\ Bharath Institute of Higher Education \& Research, Osudu Agaram Village, Villianur Commune, \\ Kudapakkam Post, Puducherry, India. ${ }^{2}$ Department of General Surgery, Sri Lakshmi \\ Narayana Institute of Medical Sciences, Bharath Institute of Higher Education \& Research, \\ Osudu Agaram Village, Villianur Commune, Kudapakkam Post, Puducherry, India.
}

\section{ABSTRACT}

\section{BACKGROUND}

Covid-19 is a new disease \& is having the most devastating effects globally; its emergence and spread causes' confusion, anxiety \& fear among the general public. The aim of the study is to evaluate the impact of Covid-19 on psychosocial and socioeconomic status of select rural and urban community during lockdown.

\section{METHODS}

We conducted a community based cross sectional study with a sample size of 600 using systematic random sampling method in both rural and urban areas of Puducherry. Pretested semi structured questionnaire was used to assess the awareness of Covid-19, psychosocial problems and socioeconomic impact.

\section{RESULTS}

Our study observed that $62 \%$ had adequate awareness, $34 \%$ had moderate awareness among the sample population and $15 \%$ had moderate to severe psychosocial impact due to lockdown, which indicates there is increased distress and apprehension among the general population due to Covid-19 pandemic. There was highly significant association between locality (urban or rural) and various psychosocial problems like feeling of yourself or others in danger.

\section{CONCLUSIONS}

There is a need for intensification of preventive aspects and stringent measures to reduce the incidence of cases in the community. To address the psychosocial impact, government can advertise the availability of helpline numbers which should be working $24 \times 7$ to fulfil the public grievances and arrange counseling specialist to tackle the mental health issues and further mitigation.

\section{KEY WORDS}

Covid-19 Awareness, Impacts, Psychosocial, Socioeconomic, Lockdown
Corresponding Author: Dr. Sivapragasam Ramalingam, Department of Community Medicine, SriLakshmi Narayana Institute of Medical Sciences, Bharath Institute of Higher Education \& Research, Osudu Agaram Village, Villianur Commune, Kudapakkam Post, Puducherry-605502, India. E-mail: sivapragasam66@gmail.com

\section{DOI: $10.14260 / j e m d s / 2020 / 847$}

How to Cite This Article: Senthil R, Kunchithapathan B, Ramalingam $S$, et al. Covid 19 awareness and its impacts in rural and urban puducherry - a community based cross sectional study. J Evolution Med Dent Sci 2020;9(51):38623867, DOI: 10.14260/jemds/2020/847

Submission 03-09-2020,

Peer Review 29-10-2020,

Acceptance 05-11-2020,

Published 21-12-2020.

Copyright (c) 2020 Rajini Senthil et al. This is an open access article distributed under Creative Commons Attribution License [Attribution 4.0 International (CC BY 4.0)] 


\section{BACKGROUND}

According to World Health Organization (WHO), viral diseases continue to emerge and represent a serious issue to public health. In the last 20 years, several epidemics such as the severe SARS corona virus (SARS-CoV) in 2002 to 2003 and H1N1 influenza in 2009, have been recorded. In the present day, an epidemic of cases with unexplained lower respiratory infections detected in Wuhan (Metropolitan area in China), was reported to WHO country office in China on December 31, 2019. The new virus was called 2019-nCoV. Experts of the International committee on Taxonomy of Virus termed it as SARS-CoV-2 virus as it is very similar to the one that caused the SARS outbreak. ${ }^{1}$ On $11^{\text {th }}$ February, WHO announced a name for the new corona virus - Covid-19 (WHO 2020C). On $11^{\text {th }}$ March, WHO declared Covid-19, a pandemic as by then about 114 countries were affected (WHO 2020C). ${ }^{2}$

Funds were raised globally 7 strategic preparedness and response plan (SPRP) was set up aimed to protect the states with weaker health systems. The targets were to limit transmission, provide early care, communicate key information \& minimize social and economic impacts. Also, WHO focused on developing easy to apply diagnostics, accelerating existing vaccine candidates \& preventing infection (WHO 2020C). ${ }^{3}$ The states of lockdown in many parts of the world, which are contributing largely to the global economy has led to the halting of services and products. This affected the global economy brutally. ${ }^{4}$ Transport business has ceased at national levels due to lockdown in many countries. Most company employees are working from home, which has its financial problems. Educational institutes got shut down \& this causes the younger minds more stressor. ${ }^{2}$

Along with economy impacts, the morbidity \& mortality rate is increasing due to Covid-19, is the biggest setback. The WHO report revealed the mortality rate to be between $3-4 \%{ }^{3}$ However it seems that the mortality statistics are underestimated. ${ }^{5}$ As Covid 19 is a new disease $\&$ is having the most devastating effects globally, its emergence and spread causes confusion, anxiety \& fear among the general public. ${ }^{2}$ It is important to avoid this stigma as it can make them to hide their illness and not seek health care immediately. The anxiety and concerns in society are globally affecting every individual to variable extents, especially people who are kept in isolation and quarantine, experience significant distress in the form of anxiety, anger, confusion \& post-traumatic stress symptoms. ${ }^{6}$

Lessons learned from the SARS outbreak in 2003, propose that knowledge \& attitudes towards infectious diseases are linked with level of panic emotion among the population, which can further complicate attempt to prevent the spread of the disease. Uncertain prognoses, approaching severe shortages of resources for testing and treatment, for protecting responders \& healthcare providers from infection, obligation of unfamiliar public health measures that infringe on personal freedoms, large \& growing financial losses and conflicting messages from authorities are among the major stressors that undoubtedly will contribute to widespread emotional distress and increased risk for psychiatric illness associated with Covid-19. Public health emergencies may affect the health safety \& wellbeing of both individuals (insecurity, confusion, emotional isolation \& stigma) and communities (owing to economic loss, work \& school closures, inadequate resources for medical response \& deficient distribution of necessities). These effects may translate into a range of emotional reactions (distress or psychiatric conditions), unhealthy behaviours (excessive substance abuse) \& noncompliance with public health directives (such as home confinement \& vaccination) in people who contract the disease $\&$ in the general population. . $^{7}$

Some people may be more vulnerable to the psychosocial conditions than others (including the elderly, people with immuno compromised function). Health care providers are also particularly vulnerable to emotional distress in the current pandemic, given their risk of exposure to virus, concern about infection, caring for their loved ones, shortages of PPE kits, longer work hours and involvement in emotionally \& ethically fraught resource allocation decisions. Beyond stresses inherent in the illness itself mass home confinement directives (including staying at home orders, quarantine \& isolation) are new to many people, so those people are more prone for psychological distress. ${ }^{4}$ Therefore this present study represents the following objectives awareness of Covid-19 and the impact of Covid-19 in psychosocial and socioeconomic status of select rural and urban community during lockdown.

\section{METHODS}

We had conducted a community based cross sectional study from April 2020 to June 2020 in the catchment area around Sri Lakshmi Narayana Institute of Medical Sciences, Puducherry.

\section{Sample Size Calculation}

Assuming $50 \%$ proportions ${ }^{10}$ of the people would be aware of COVID 19 and tolerable error as 4 at $95 \%$ confidence interval, calculated sample size was found to be around 625 .

\section{Sampling Technique}

Villianur taluk is located in Puducherry district. It is one of 4 taluks of Puducherry district. There are 36 villages and 3 towns in Villianur taluk. As per the Census India 2011,11 Villianur taluk has 50384 households, population of 213278 of which 105674 are males and 107604 are females. The total area of Villianur taluk is 130.40 sq. Km with population density of 1636 per sq. Km. Out of total population, $68.47 \%$ of population lives in urban area and $31.53 \%$ lives in rural area. The households for current study was selected by using multistage sampling technique to arrive a sampling frame of 300 rural and 300 urban households. Villianur is divided into urban and rural strata i.e. town and villages. Since only 3 towns was available, all 3 towns was selected representing 100 houses from each town whereas considering 60 houses in each village, five villages was selected out of 36 villages by systematic random sampling, with a sampling interval of 7 . The chosen villages are Koodapakkam, Ossudu, Thondamanatham, Uruvaiyar and Katteri. To ensure equal representation in all towns and all villages, equal number of people were taken from all the selected villages and towns making it to 100 household per town and 60 per villages. The 60 houses in each village, 100 houses from each town was selected using systematic random sampling with a sampling interval according to each village and town census. 


\section{Study Population}

One individual from each household, who is 18 yrs. and above and who is willing to participate with informed consent was included in the study. Locked households (after 3 attempts) were excluded.

\section{Statistical Analysis}

Proportions were used for descriptive data. Chi square test for independence was used to find the association between socio demographic variables and various domains of Covid-19 awareness, psychosocial problems and socioeconomic impacts. The collected data were entered into a Microsoft Excel 2013 and were analysed using statistical software SPSS 21 version (IBM SPSS Software, USA).

\section{Study Tool and Data Collection Instruments}

Study tool is a self-administered pretested semi structured tool which was face and content validated by the authors and external experts in the field of public health. The first part of the questionnaire contained the details regarding socio demographic variables like age, gender, occupation, education, family type, marital status, family income. BG Prasad socioeconomic scale ${ }^{7}$ was used to determine the socio economic status. The second part of questionnaire was divided into three domains i.e. awareness of Covid-19, psychosocial problems and socioeconomic impact domains. Covid-19 awareness domain had been framed based on symptoms, signs, precaution, prevention, when and how to seek health care and role in preventing community spread. The psychosocial problems were framed based on thoughts about Covid-19 anxiety, suffering due to hunger, illness or inability to attend family events and violence faced in home, which was calculated using self-administered semi structured tool which was face and content validated by the authors and external experts in the field of public health. The responses given by participants are then allotted with raw scores. The final scores for awareness of Covid-19 were quantified as; total scores 8 to 10 as aware of Covid-19, scores 5 to 7 as moderately aware and scores less than 4 as unaware. Scores were ranging from 1 to 10 , these scores were converted into three categories which were split equally. The final scores for psychosocial problems were quantified as mild, moderate and severe with scores 1 to 4,5 to 7 and 8 to 10 respectively. The socioeconomic impact due to Covid-19 was framed based on economic loss, difficulties in paying rentals / loans, material loss, methods of overcoming financial crisis support from government or NGO.

\section{Method of Data Collection}

The study subjects were interviewed in their homes by trained interns after getting informed consent. The socio demographic variables, Covid-19 awareness scale, psychosocial problems and socioeconomic impacts was used to collect data from them under the supervision of the investigators.

\section{Ethical Considerations}

Scientific and ethical approval was taken from the Institutional Ethics Committee, of Sri Lakshmi Narayana Institute of Medical Sciences, Puducherry, before conducting the present study. We explained about our study and its importance to the participants in vernacular language, Tamil. Anonymity and confidentiality were ensured throughout the study.

\section{RESULTS}

\begin{tabular}{|c|c|c|c|}
\hline Sl. No. & Variables & Frequency $(N=600)$ & Percentage \\
\hline \multirow{5}{*}{1.} & Age category & & \\
\hline & 18 to $35 \mathrm{yrs}$. & 168 & $28 \%$ \\
\hline & 36 to $50 \mathrm{yrs}$. & 285 & $47.5 \%$ \\
\hline & 51 to 65 yrs. & 125 & $20.8 \%$ \\
\hline & 66 and above yrs. & 22 & $3.7 \%$ \\
\hline \multirow{3}{*}{2.} & Gender & & \\
\hline & Male & 395 & $68.84 \%$ \\
\hline & Female & 205 & $34.15 \%$ \\
\hline \multirow{8}{*}{3.} & Education & & \\
\hline & Illiterate & 82 & $13.6 \%$ \\
\hline & Primary school & 44 & $7.3 \%$ \\
\hline & Middle school & 74 & $12.3 \%$ \\
\hline & High school & 115 & $19.1 \%$ \\
\hline & Higher secondary & 89 & $14.8 \%$ \\
\hline & Graduate & 120 & $20 \%$ \\
\hline & Post Graduate and above & 76 & $12.6 \%$ \\
\hline \multirow{3}{*}{4.} & Residence & & \\
\hline & Urban & 300 & $50 \%$ \\
\hline & Rural & 300 & $50 \%$ \\
\hline \multirow{6}{*}{5.} & Income & & \\
\hline & Less than 5000 & 187 & $31.1 \%$ \\
\hline & 5001 to 10000 & 172 & $28.7 \%$ \\
\hline & 10001 to 30000 & 122 & $20.3 \%$ \\
\hline & 30001 to 50000 & 81 & $13.5 \%$ \\
\hline & Above 50000 & 38 & $6.3 \%$ \\
\hline \multirow{15}{*}{6.} & Occupation & & \\
\hline & Business & 62 & $10.3 \%$ \\
\hline & Manager & 25 & $4.1 \%$ \\
\hline & Shopkeeper & 39 & $6.5 \%$ \\
\hline & Farmer & 88 & $14.6 \%$ \\
\hline & Company worker & 17 & $2.8 \%$ \\
\hline & Homemaker & 105 & $17.5 \%$ \\
\hline & Professional & 48 & $8 \%$ \\
\hline & Student & 41 & $6.8 \%$ \\
\hline & Teacher & 24 & $4 \%$ \\
\hline & No occupation / retired & 78 & $13 \%$ \\
\hline & Coolie & 15 & $2.5 \%$ \\
\hline & Driver & 9 & $1.5 \%$ \\
\hline & EB department & 19 & $3.1 \%$ \\
\hline & Clerical & 30 & $5 \%$ \\
\hline
\end{tabular}

\begin{tabular}{|c|c|c|c|c|c|c|}
\hline Sl. No. & $\begin{array}{c}\text { Psychosocial } \\
\text { Problem } \\
\text { Variables }\end{array}$ & Options & Rural & Urban & $\begin{array}{c}\text { Chi } \\
\text { Square }\end{array}$ & $\begin{array}{c}\mathbf{P} \\
\text { Value }\end{array}$ \\
\hline 1. & $\begin{array}{c}\text { Feeling yourself } \\
\text { or others in } \\
\text { danger }\end{array}$ & $\begin{array}{l}\text { Yes }(27.1 \%) \\
\text { No }(72.8 \%)\end{array}$ & $\begin{array}{l}124(20.6 \%) \\
176(29.3 \%)\end{array}$ & $\begin{array}{c}39(6.5 \%) \\
261(43.5 \%)\end{array}$ & 60.85 & 0.000 \\
\hline 2. & $\begin{array}{l}\text { Feel that you } \\
\text { might be } \\
\text { affected with } \\
\text { COVID } 19\end{array}$ & $\begin{array}{l}\text { Yes }(22.3 \%) \\
\text { No }(77.6 \%)\end{array}$ & $\begin{array}{c}90(15 \%) \\
210(35 \%)\end{array}$ & $\begin{array}{c}44(7.3 \%) \\
256(42.6 \%)\end{array}$ & 20.33 & 0.000 \\
\hline 3. & $\begin{array}{l}\text { Feeling anxious } \\
\text { or helpless }\end{array}$ & $\begin{array}{l}\text { Yes }(16.6 \%) \\
\text { No }(83.3 \%)\end{array}$ & $\begin{array}{c}70(11.6 \%) \\
230(38.3 \%)\end{array}$ & $\begin{array}{c}30(5 \%) \\
270(45 \%)\end{array}$ & 19.2 & 0.000 \\
\hline 4. & $\begin{array}{l}\text { Suffering away } \\
\text { from family } \\
\text { members }\end{array}$ & $\begin{array}{l}\text { Yes }(11.5 \%) \\
\text { No }(88.5 \%)\end{array}$ & $\begin{array}{c}45(7.5 \%) \\
255(42.5 \%)\end{array}$ & $\begin{array}{c}24(4 \%) \\
276(46 \%)\end{array}$ & 7.22 & 0.007 \\
\hline 5. & $\begin{array}{l}\text { Suffered from } \\
\text { hunger }\end{array}$ & $\begin{array}{l}\text { Yes }(19.2 \%) \\
\text { No }(80.6 \%)\end{array}$ & $\begin{array}{c}76(12.6 \%) \\
224(37.3 \%)\end{array}$ & $\begin{array}{c}40(6.6 \%) \\
260(43.3 \%)\end{array}$ & 13.8 & 0.000 \\
\hline 6. & $\begin{array}{l}\text { Not able to seek } \\
\text { healthcare }\end{array}$ & $\begin{array}{l}\text { Yes }(14 \%) \\
\text { No }(86 \%)\end{array}$ & $\begin{array}{c}51(8.5 \%) \\
249(41.5 \%)\end{array}$ & $\begin{array}{c}33(5.5 \%) \\
267(44.5 \%)\end{array}$ & 4.48 & 0.03 \\
\hline 7. & $\begin{array}{l}\text { Suffered from } \\
\text { not attending } \\
\text { important } \\
\text { gathering or } \\
\text { death }\end{array}$ & $\begin{array}{l}\text { Yes }(31.5 \%) \\
\text { No }(68.5 \%)\end{array}$ & $\begin{array}{l}111(18.5 \%) \\
189(31.5 \%)\end{array}$ & $\begin{array}{c}78(13 \%) \\
222(37 \%)\end{array}$ & 8.4 & 0.004 \\
\hline 8. & $\begin{array}{l}\text { Suffered any } \\
\text { type physical or } \\
\text { verbal abuse }\end{array}$ & $\begin{array}{l}\text { Yes }(27.1 \%) \\
\text { No }(72.8 \%)\end{array}$ & $\begin{array}{c}75(12.5 \%) \\
225(37.5 \%)\end{array}$ & $\begin{array}{c}88(14.6 \%) \\
212(35.3 \%)\end{array}$ & 1.42 & 0.23 \\
\hline
\end{tabular}




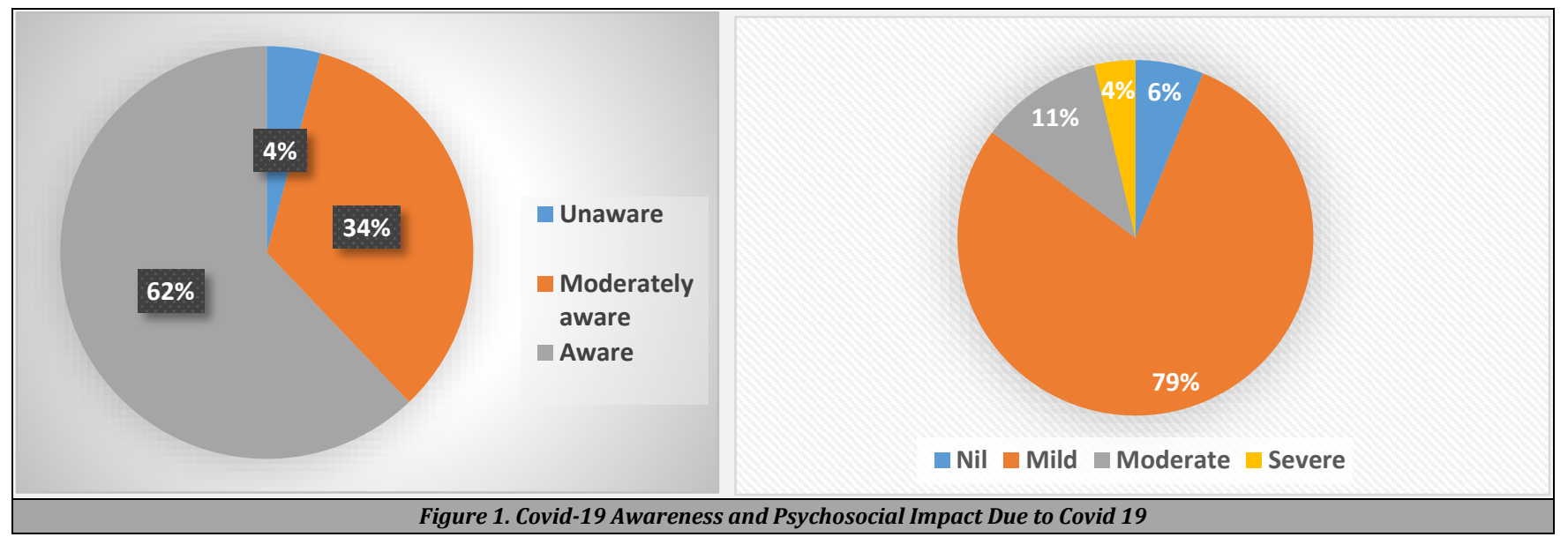

\begin{tabular}{|c|c|c|c|c|c|c|c|}
\hline SI. No. & Psychosocial Problem Variables & Options & Unaware & Moderately Aware & Aware & Chi Square & P Value \\
\hline 1. & Feeling yourself or others in danger & $\begin{array}{l}\text { Yes }(27.1 \%) \\
\text { No }(72.7 \%)\end{array}$ & $\begin{array}{c}3(0.5 \%) \\
22(3.6 \%)\end{array}$ & $\begin{array}{c}72(12 \%) \\
130(21.6 \%)\end{array}$ & $\begin{array}{c}88(14.6 \%) \\
285(47.5 \%)\end{array}$ & 12.651 & 0.002 \\
\hline 2. & Feel that you might be affected with COVID 19 & $\begin{array}{l}\text { Yes }(22.2 \%) \\
\text { No }(77.6 \%)\end{array}$ & $\begin{array}{l}7(1.1 \%) \\
18(3 \%)\end{array}$ & $\begin{array}{c}55(9.1 \%) \\
147(24.5 \%)\end{array}$ & $\begin{array}{c}72(12 \%) \\
301(50.1 \%)\end{array}$ & 5.227 & 0.73 \\
\hline 3. & Feeling anxious or helpless & $\begin{array}{l}\text { Yes }(16.5 \%) \\
\text { No }(88.4 \%)\end{array}$ & $\begin{array}{l}7(1.1 \%) \\
18(3 \%)\end{array}$ & $\begin{array}{c}59(9.8 \%) \\
143(23.8 \%)\end{array}$ & $\begin{array}{c}34(5.6 \%) \\
339(56.5 \%)\end{array}$ & 40.50 & 0.00 \\
\hline 4. & Suffering away from family members & $\begin{array}{l}\text { Yes }(11.4 \%) \\
\text { No }(88.4 \%)\end{array}$ & $\begin{array}{c}2(0.3 \%) \\
23(3.8 \%)\end{array}$ & $\begin{array}{c}37(6.1 \%) \\
165(27.5 \%)\end{array}$ & $\begin{array}{c}30(5 \%) \\
343(57.1 \%)\end{array}$ & 13.90 & 0.001 \\
\hline 5. & Suffered from hunger & $\begin{array}{l}\text { Yes }(19.3 \%) \\
\text { No }(80.5 \%)\end{array}$ & $\begin{array}{l}11(1.8 \%) \\
14(2.3 \%)\end{array}$ & $\begin{array}{c}39(6.5 \%) \\
163(27.1 \%)\end{array}$ & $\begin{array}{c}66(11 \%) \\
307(51.1 \%)\end{array}$ & 10.39 & 0.006 \\
\hline 6. & Not able to seek healthcare & $\begin{array}{l}\text { Yes }(13.9 \%) \\
\text { No }(85.9 \%)\end{array}$ & $\begin{array}{c}2(0.3 \%) \\
23(3.8 \%)\end{array}$ & $\begin{array}{c}37(6.1 \%) \\
165(27.5 \%)\end{array}$ & $\begin{array}{c}45(7.5 \%) \\
328(54.6 \%)\end{array}$ & 5.03 & 0.08 \\
\hline 7. & Suffered from not attending important gathering or death & $\begin{array}{l}\text { Yes }(31.4 \%) \\
\text { No }(68.4 \%)\end{array}$ & $\begin{array}{c}5(0.8 \%) \\
20(3.3 \%)\end{array}$ & $\begin{array}{c}66(11 \%) \\
136(22.6 \%)\end{array}$ & $\begin{array}{l}118(19.6 \%) \\
255(42.5 \%)\end{array}$ & 1.66 & 0.43 \\
\hline 8. & Suffered any type physical or verbal abuse & $\begin{array}{l}\text { Yes }(27.1 \%) \\
\text { No }(72.7 \%) \\
\end{array}$ & $\begin{array}{c}5(0.8 \%) \\
20(3.3 \%) \\
\end{array}$ & $\begin{array}{c}27(4.5 \%) \\
175(29.1 \%) \\
\end{array}$ & $\begin{array}{l}131(21.8 \%) \\
242(40.3 \%) \\
\end{array}$ & 32.01 & 0.000 \\
\hline
\end{tabular}

The study group consisted of 600 individuals above 18 yrs. Data was collected through face-to-face interview through Covid-19 awareness and its impact questionnaire model framed by us. In our study group $47.5 \%$ were from age 36 to 50 yrs., $28 \%$ of them belonged to 18 to $35 \mathrm{yrs}$. and around 25 $\%$ belonged to 51 and above yrs. $69 \%$ belonged to male gender and $34 \%$ belonged to female gender. About $13.6 \%$ of the population were illiterate and rest all were above primary school to postgraduates. $50 \%$ each residing in urban and rural jurisdictions. Around $31 \%$ had income less than $5000 /$ month, $28 \%$ had income 5000 to $10000,20.3 \% 10000$ to 30000, $20 \%$ above 30000 per month. Our study population covered a wide range of occupation like farmers $14.6 \%$, business $10 \%$, professionals $8 \%$, rest all group C, group D workers, homemakers and retired personals from Table 1 .

Figure 1 shows that $62 \%$ of our study population were aware of Covid-19, $34 \%$ were moderately aware and $4 \%$ unaware and about $79 \%$ of the study population had mild psychosocial impact, $11 \%$ had moderate psychosocial impact and $4 \%$ had severe psychosocial impact. Table 2 shows that almost $19 \%$ of the study population had suffered from hunger during the lockdown and $27 \%$ of the study population suffered from physical or verbal abuse. Table 2 shows that there are significant association between awareness of Covid19 and various psychosocial variables like feeling yourself or others in danger $(\mathrm{p}<0.05)$, feeling anxious or helpless $(\mathrm{p}<$ $0.05)$, suffering away from family members ( $p<0.001)$, suffered from hunger $(\mathrm{p}<0.05)$ and suffered from physical or verbal abuse $(p<0.001)$.

\begin{tabular}{|c|c|c|c|c|c|}
\hline $\begin{array}{l}\text { Sl. } \\
\text { No. }\end{array}$ & Variable $(N=600)$ & Rural & Urban & $\begin{array}{c}\text { Chi } \\
\text { Square }\end{array}$ & $\begin{array}{c}P \\
\text { Value }\end{array}$ \\
\hline 1. & $\begin{array}{c}\text { Awareness Grade } \\
\text { Unaware } \\
\text { Moderately aware } \\
\text { Aware }\end{array}$ & $\begin{array}{c}21(3.5 \%) \\
141(23.5 \%) \\
138(23 \%)\end{array}$ & $\begin{array}{c}4(0.6 \%) \\
61(10.16 \%) \\
235(39.1 \%)\end{array}$ & 68.46 & 0.000 \\
\hline 2. & $\begin{array}{c}\text { Psychosocial problem } \\
\text { Nil } \\
\text { Mild } \\
\text { Moderate } \\
\text { Severe } \\
\end{array}$ & $\begin{array}{c}34(5.6 \%) \\
221(36.8 \%) \\
32(5.3 \%) \\
13(2.1 \%) \\
\end{array}$ & $\begin{array}{c}3(0.5 \%) \\
253(42.1 \%) \\
35(5.8 \%) \\
9(1.5 \%) \\
\end{array}$ & 28.9 & 0.000 \\
\hline & 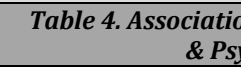 & & 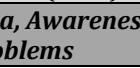 & & \\
\hline
\end{tabular}

Similarly, in Table 3 there was highly significant association between locality (urban or rural) and various psychosocial problems like feeling yourself or others in danger ( $\mathrm{p}<0.001$ ), feeling that you might be affected with Covid-19 ( $\mathrm{p}$ $<0.001)$, feeling anxious or helpless ( $<<0.001)$, suffered from hunger $(\mathrm{p}<0.001)$ and significant association with suffering away from family members $(p<0.05)$, suffered from not attending gatherings $(\mathrm{p}<0.05)$, not able to seek health care ( $p$ $<0.05$ ). Table 4 shows highly significant associations between locality (urban or rural) and Covid-19 awareness grades ( $\mathrm{p}<$ $0.001)$, and psychosocial problems levels $(\mathrm{p}<0.001)$.

The present study showed about $45 \%$ of our study population disagree to enjoy spending time with family during 
lockdown. Almost $86 \%$ accepted lockdown was effective (41 $\%$ completely effective and $45 \%$ effective to some extent).

\section{DISCUSSION}

The present study reports $62 \%$ of the individuals are well aware of the current pandemic situation of Covid-19. The awareness status of the participants includes signs \& symptoms, mode of spread, prevention of Covid etc. In a study, done among Healthcare Students and Professionals at Mumbai, says $62 \%$ of the respondents were aware regarding Covid 19, its route of transmission, signs and symptoms of the infection. $52.5 \%$ of them were well aware of the preventive measures to safeguard themselves against Covid-19.12

The perception of the study visualizes the psychosocial as well as the economic stresses due to Covid-19 pandemic in India. This study shows $79 \%$ of the participants had undergone the psychosocial impact due the pandemic of corona virus. The suffered population has faced problems like, staying away from family members, hunger or no food, not attending important social gatherings, not able to seek health care facilities, delay in treatment, etc. Similarly, many of the articles by Jacobson D, Gupta R, Singh AK at al. has quoted, many of the population has faced psychosocial problems during the lockdown period.13-16

The study also reports, $20 \%$ of the study population has undergone difficulties like verbal or physical abuse by their family members during this pandemic. Similar results were observed in the Mail Today Bureau, ${ }^{17}$ the cases of domestic or gender-based violence has doubled during lockdown compared to pre-lockdown days. ${ }^{18}$

Many studies have been done on various levels of knowledge and practice of other respiratory infections, whereas only limited studies have been done on the awareness level of Covid-19 among rural and urban population. The pandemic situation of Covid-19 has initiated the need for timely attention to the population, to prevent long-lasting adverse health outcomes.

\section{CONCLUSIONS}

Our study observed that $62 \%$ had adequate awareness and 34 $\%$ had moderate awareness among the sample population. In spite of $62 \%$ awareness, there is a rise in the number of Covid positive cases on daily basis which indicates further intensification of preventive aspects and stringent measures to reduce the incidence of cases in the community.

This study reports $15 \%$ of moderate to severe psychosocial impact due to lockdown, which indicates that there is increased distress and apprehension among the general population due to Covid-19 pandemic. To address the psychosocial impact, government can advertise the availability of helpline numbers which should be working $24 \times 7$ to fulfil the public grievances and arrange counselling specialist to tackle the mental health issues and further mitigation

Data sharing statement provided by the authors is available with the full text of this article at jemds.com.

Financial or other competing interests: None.
Disclosure forms provided by the authors are available with the full text of this article at jemds.com.

\section{REFERENCES}

[1] WHO. Naming the coronavirus disease (COVID 19) and the virus that causes it. 2020. https://www.who.int/emergencies/diseases/novelcoronavirus-2019/technical-guidance/naming-thecoronavirus-disease-(covid-2019)-and-the-virus-thatcauses-it.

[2] WHO. Coronavirus disease (COVID 19) situation report 46. World Health Organisation 2020. https://www.who.int/docs/defaultsource/coronaviruse/situation:reports/20200306sitrep-46-covid-19.pdf?sfvrsn=96B04adf2

[3] World Health Oraganisation. Rolling updates on coronavirus disease (COVID - 19). 2020 https://www.who.int/emergencies/disease/novelcoronavirus-2019/events-as-they-happen

[4] Ebrahim SH, Ahmed QA, Gozzer E, et al. Covid-19 and community mitigation strategies in a pandemic. BMJ 2020;368:m1066.

[5] Baud D, Qi X, Nielsen-Saines K, et al. Real estimates of mortality following COVID-19 infection. Lancet Infect Dis 2020;20(7):773.

[6] Brooks SK, Webster RK, Smith LE, et al. The psychological impact of quarantine and how to reduce it: rapid review of the evidence. Lancet 2020;395(10227):912-20.

[7] Person B, Sy F, Holton K, et al. National center for infectious diseases SCOT. Fear and stigma: the epidemic within the SARS outbreak. Emerge Infect Dis 2004;10(2):358-63.

[8] Tao N. An analysis on reasons of SARS induced psychological panic among students. Journal of Anhui Institute of Education 2003;21:78-9.

[9] American Psychiatric Association. Trauma \& stressor related disorders. In: Diagnostic \& statistical manual of mental disorders. $5^{\text {th }}$ edn. Arlington VA: American Psychiatric Publishing 2013. p. 265-90.

[10] Antonisamy B, Premkumar P, Christopher S. Sample size. In: Principles and practice of biostatistics. $1^{\text {st }}$ edn. New Delhi: Elsevier 2017. p. 315.

[11] Census India 2011. https://www.censusindia2011.com/puducherry/puduc herry/villianur-taluk-

[12] Modi PD, Nair G, Uppe A, et al. COVID-19 Awareness among healthcare students and professionals in mumbai metropolitan region: a questionnaire- based survey. Cureus 2020;12(4):e7514.

[13] Jacobson D. Indian society and ways of living. Asia Soc 2020. https://asiasociety.org/education/indian-societyand-ways-living

[14] Gupta R, Hussain A, Misra A. Diabetes and COVID-19: evidence, current status and unanswered research questions. Eur J Clin Nutr 2020;74(6):864-70.

[15] Singh AK, Gupta R, Misra A. Comorbidities in COVID-19: outcomes in hypertensive cohort and controversies with renin angiotensin system blockers. Diabetes Metab Syndr 2020;14(4):283-7. 
[16] Web Desk. Young old, male or female: $86 \%$ of 111 who died of COVID-19 had one factor in common. April 2020 https://www.theweek.in/news/india/2020/04/07/you ng-old-male-female-86-per-cent-of-111-covid-19deaths-had-one-factor-in-common.html

[17] Moses NV. COVID-19: India is staring at a mental health crisis. Hind 2020 https://www.hindustantimes.com/analysis/covid-19- india-is-staring-at-a-mental-health-crisis/storyhmBOzUYsbo3SmtlWilmBzL.html

[18] Mail Today Bureau. Domestic violence spikes in lockdown, Govt. told to step in 2020. https://www.indiatoday.in/mail-today/story/domesticviolence-spikes-in-lockdown-govt-told-to-step-in1671460-2020-04-27. 